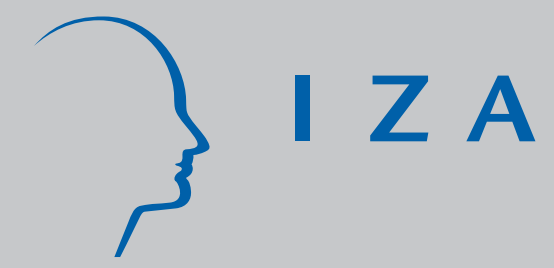

IZA DP No. 2204

Education Policy and Intergenerational Income Mobility: Evidence from the Finnish Comprehensive School Reform

Tuomas Pekkarinen

Roope Uusitalo

Sari Pekkala

J uly 2006 


\title{
Education Policy and Intergenerational Income Mobility: Evidence from the Finnish Comprehensive School Reform
}

\author{
Tuomas Pekkarinen \\ Uppsala University \\ and IZA Bonn \\ Roope Uusitalo \\ Labour Institute for Economic Research, Helsinki \\ Sari Pekkala \\ Government Institute for Economic Research, Helsinki
}
Discussion Paper No. 2204
July 2006

\author{
IZA \\ P.O. Box 7240 \\ 53072 Bonn \\ Germany \\ Phone: +49-228-3894-0 \\ Fax: +49-228-3894-180 \\ Email: iza@iza.org
}

\begin{abstract}
Any opinions expressed here are those of the author(s) and not those of the institute. Research disseminated by IZA may include views on policy, but the institute itself takes no institutional policy positions.

The Institute for the Study of Labor (IZA) in Bonn is a local and virtual international research center and a place of communication between science, politics and business. IZA is an independent nonprofit company supported by Deutsche Post World Net. The center is associated with the University of Bonn and offers a stimulating research environment through its research networks, research support, and visitors and doctoral programs. IZA engages in (i) original and internationally competitive research in all fields of labor economics, (ii) development of policy concepts, and (iii) dissemination of research results and concepts to the interested public.
\end{abstract}

IZA Discussion Papers often represent preliminary work and are circulated to encourage discussion. Citation of such a paper should account for its provisional character. A revised version may be available directly from the author. 


\begin{abstract}
Education Policy and Intergenerational Income Mobility: Evidence from the Finnish Comprehensive School Reform ${ }^{*}$

Many authors have recently suggested that the heterogeneity in the quality of early education may be one of the key mechanisms underlying the intergenerational persistence of earnings. This paper estimates the effect of a major educational reform on the intergenerational income mobility in Finland. The Finnish comprehensive school reform of 1972-1977 significantly reduced the degree of heterogeneity in the Finnish primary and secondary education. The reform shifted the tracking age in secondary education from age 10 to 16 and imposed a uniform academic curriculum on entire cohorts until the end of lower secondary school. We estimate the effect of the reform on the correlation between son's earnings in 2000 and father's average earnings during 1970-1990 using a representative sample of males born during 1960-1966. The identification strategy relies on a difference-in-differences approach and exploits the fact that the reform was implemented gradually across municipalities during a six-year period. The results indicate that the reform reduced the intergenerational income correlation by seven percentage points.
\end{abstract}

JEL Classification: D31, J62, I20

Keywords: generational mobility, education, comprehensive school reform

Corresponding author:

Tuomas Pekkarinen

Uppsala University

Department of Economics, Box 513

75120 Uppsala

Sweden

E-mail: tuomas.pekkarinen@nek.uu.se

\footnotetext{
* The authors would like to thank the seminar participants in Mannheim, Stockholm, Turku, and Uppsala for helpful comments. The usual disclaimer applies. Furthermore, the authors are grateful to the Statistics Finland and especially Marianne Johnson and Christian Starck for the help with the data. Pekkarinen gratefully acknowledges the financial support from Yrjö Jahnson Foundation.
} 


\section{Introduction}

One of the key questions in the study of economic inequality is the degree to which the economic status is transferred within families. It is often argued that high cross-sectional inequality is socially more sustainable if it is accompanied with high intergenerational mobility. In a highly mobile society, each incoming cohort is faced with equal opportunities to climb up the income distribution and neither wealth nor poverty is necessarily inherited from parents.

The most common approach to study intergenerational income mobility in economics is to estimate correlations of lifetime earnings of fathers and their sons. More than two decades of research on these correlations has shown that there are large differences across countries. Intergenerational income correlations are high (around 0.4) in the United States and the United Kingdom and much lower low (around 0.2) in Canada, Finland, and Sweden. ${ }^{1}$ Recent research also indicates that these correlations have been increasing in the United States and the United Kingdom over the last two decades. In Finland, on the other hand, intergenerational income correlation has followed a steady downward trend over last thirty years. ${ }^{2}$

Apart from these facts, however, little is known about the mechanisms underlying the intergenerational income correlations or about the reasons behind the cross-country differences. Also, even though recent research has started to document changes in social mobility, there is little hard evidence on the causes of the observed changes. Perhaps most importantly, there is no evidence on the effects of feasible policy instruments that could affect income mobility. Still it would be interesting to know whether programs that aim to alleviate the adverse effects of poor family background actually succeed in equalizing economic opportunities.

In this paper, we estimate the effects of one such policy by examining the impacts of the Finnish comprehensive school reform. This reform was implemented during 19721977 and it completely changed the structure and the content of the Finnish primary and secondary education. As a result of the reform, tracking into academic and vocational secondary schools was postponed from age 11 to age 16 and a uniform academic curriculum was imposed on the entire cohort until age 16. The reform thus significantly reduced the heterogeneity in the quality, and to a lesser extent in the quantity, of primary and secondary education. The implementation of the reform was phased so that different municipalities adopted the reform at different times. This gradual adoption of the reform allows us treat it as a quasi-experiment and to estimate the effect of the reform on the intergenerational income correlation using a differences-in-differences approach.

The Finnish comprehensive school reform is a good example of the educational reforms that were implemented in Europe after the second world war. Very similar reforms took place in Sweden in the 1950s and in Norway in the 1960s. ${ }^{3}$ These reforms were seen as an integral part in the building of modern welfare state and one of the main motivations for their implementation was precisely to enhance the equality of opportunity.

The effects of these reforms are also interesting because educational policies play a key role in the theoretical literature on intergenerational income mobility, starting from the work by Becker and Tomes $(1979,1986)$ and developed by Solon (2004). More recently,

\footnotetext{
${ }^{1}$ See Solon (1992) and Zimmerman (1992) on US; Dearden, Machin, and Reed (1997) on UK; Corak and Heisz (1999) on Canada; Björklund and Jäntti (1997) on Sweden; and Österbacka (2001) on Finland).

${ }^{2}$ See Aaronson and Mazumder (2005) on the trends in the US; Blanden, Goodman, Gregg, and Machin (2004) on the trends in the UK, and Pekkala and Lucas (2006) on the trends in Finland. Interestingly, Pekkala and Lucas also demonstrate that the decrease in intergenerational correlation in Finland is mainly due to a decrease in the returns to education and to a more equal distribution of education.

${ }^{3}$ See Lechinsky and Mayer (1990) for an overview of the comprehensive school reforms in post-war Europe.
} 
Restuccia and Urrutia (2004) have presented a model that distinguishes between early and late education and argue that the intergenerational income persistence is driven by parental investment in the primary and secondary education of their children. This model is in line with the growing literature on the technology of the skill formation surveyed by Carneiro and Heckman (2003) as well as Cunha, Heckman, Lochner, and Masterov (2006). According to these authors, the production of human capital is characterized by the strong complementarity of skills that are acquired early and investment in later education. Hence, policy interventions that target early education of individuals from a disadvantaged background will increase the returns to both private and public investment in post-secondary education, and are likely to lead to increased income mobility.

Finally, there is some evidence that suggests that the aspects of the educational systems such as tracking and the heterogeneity in the quality of early education affect intergenerational income mobility. Dustmann (2004) argues that high intergenerational income correlation in Germany is at least partly due to the German educational system where pupils are tracked to academic and vocational schools already at the age of 10 . In line with this argument, Meghir and Palme (2004) demonstrate that the comprehensive school reform in Sweden had a particularly strong effect on the education and income of high ability pupils with less educated parents.

We estimate the effect of the reform on the elasticity of son's earnings in 2000 with respect to father's average earnings during 1970-1990 using a representative sample of males born between 1960-1966. The identification strategy relies on a differences-in-differences approach and exploits the fact that the reform was implemented gradually across municipalities during a six-year period. The overall intergenerational income elasticity in this sample is 0.28 , close to the previous estimates of income mobility in Finland. The reform decreased the intergenerational income elasticity by approximately seven percentage points from the pre-reform elasticity of 0.30 or by approximately 20 percent.

The paper is organized as follows. In the following section, we describe the Finnish comprehensive school reform in detail and argue why it provides a good natural experiment to study the effects of educational policies on intergenerational income correlation. Our identification strategy is described in more detail in section 3. We then present the sample from the Finnish Longitudinal Census Data Files that we use in our analysis and in the fifth section we present the results. The sixth section concludes.

\section{The Finnish comprehensive school reform 1972-1977}

Finland followed the example of her Nordic neighbors and introduced a thorough comprehensive school reform in the 1970's. Similar reforms had already taken place earlier in Sweden and Norway. These reforms are described in detail in Meghir and Palme (2004) and Aalvik, Salvanes and Vaage (2003). The main motivation for the reform was to provide equal educational opportunities to all students irrespective of place of residence or social background. Still the most important factor was probably rapid re-structuring of Finnish economy. The demand for low-skill labor in small farms and forestry had decreased rapidly. The growing industrial sector increased the demand for skilled workers.

Prior to the comprehensive school reform, Finland had a two-track school system. In this system, cohorts attended uniform education only for four years after which they were divided into two tracks that differed both in the content of education, as well as, in the eligibility that they provided for further education.

The pre-reform system is described schematically in the left-hand panel of Figure 1. All students entered primary school (kansakoulu) at age seven. After four years in the primary school, at age 11, the students were faced with the choice of applying to general secondary school (oppikoulu) or continuing in the primary school. Admissions to the gen- 
eral secondary school were based on an entrance examination (50\%), a teacher assessment and primary school grades. Those who were admitted continued their schooling in the junior secondary schools for five years and often went on to the upper secondary school for three additional years. At the end of the upper secondary school the students took the matriculation examination that provided eligibility to university-level studies.

Those who were not admitted or who did not apply to the general secondary school continued in primary school for two more years, and spent in total six years in the primary school. By the beginning of 1970s most primary schools had continuation classes (civic schools) that kept almost the whole age cohort at school up to the 8th (and in many municipalities 9th) grade. This education did not provide eligibility for senior secondary school or for university studies. After civic school most students continued into vocational education or finished their schooling.

In 1970, most secondary schools were private. About 55 percent of all general secondary school students attended these private schools. The private schools collected student fees but received most of their funding as state aid and contributions from local municipalities. The fraction of students in the state schools was about 30 percent. The remaining 15 percent attended municipality-run secondary schools, mostly founded during the 1960s.

[FIGURE 1 SCHOOL SYSTEMS]

The curriculum in general secondary schools was very different from the more practical civic schools. For example, foreign languages were compulsory only in the general secondary school. These schools also taught more advanced mathematics and science whereas the focus in civic schools was on practical skills required in low-skill occupations.

\subsection{Content of the comprehensive school reform}

The school system was reformed in the 1970s. The reform introduced a new curriculum and changed the structure of primary and secondary education. The new curriculum increased the academic content of education compared to the old primary school curriculum by increasing the share of mathematics and sciences. In addition, one foreign language became compulsory for all students. Thus, the new comprehensive school curriculum resembled the old general secondary school curriculum and exposed the pupils who, in the absence of the reform, would have stayed in the primary school to a significantly more academic education.

The post-reform system is described in the right-hand panel of figure 1. Previous primary school, civic school and junior secondary school were replaced by a nine-year comprehensive school. At the same time upper secondary school was separated from the junior secondary school to form a distinct form of institution. Thus, after the reform, all the pupils followed the same curriculum in the same establishments (comprehensive schools) up to age 16. After this, the students chose between applying to upper secondary school or to vocational schools. Admission to both tracks was based solely on comprehensive school grades.

Hence, the main changes that followed the reform were the postponement of tracking from the age 11 to 16 and the increase in the academic content of the curriculum. In addition to these fundamental changes, the reform also imposed a centralized control on schools at the national level and almost abolished the extensive network of private schools that had run general secondary school system by placing them under municipal ownership. 


\subsection{The implementation of the comprehensive school reform}

The implementation of the reform was preceded by a process of planning that lasted for two decades. Government working groups had proposed creating comprehensive school already in 1948, 1957, 1959, and 1965. The first experimental comprehensive schools started their operation in 1967. Finally, in 1968 the parliament approved School Systems Act (467/1968) according to which the two track school system would be gradually replaced with a nine-year comprehensive school. The adoption of the new school system was to take place between 1972 and 1977 and the order in which the municipalities adopted the reform was to be determined by geography starting from the Northern Finland where access to education was most limited. A regional implementation plan divided the country into implementation regions and dictated when each region would adopt the comprehensive school system. Regional school boards were created to oversee the transition process.

In each region, the five lowest primary school grades were to start in the comprehensive school immediately during the fall term of the year when the region was supposed to start implementing the reform according to the regional implementation plan. After this, each incoming cohort would start their schooling in the comprehensive school. The pupils that were already above the fifth grade in the year that the region started the reform would complete their schooling according to the pre-reform system. Thus, in each region it took approximately four years to complete the reform so that all the pupils in the grades 1-9 were in the comprehensive school.

Figure 2 illustrates how the reform spread through the Finnish municipalities during 1972-1977. The first municipalities that adopted the reform in 1972 were predominantly situated in the northernmost province of Lapland. In 1973 the reform was mostly adopted in the north-eastern regions. From thereon, the reform spread so that it was adopted in 1974 in the northwest, in 1975 in south-east, in 1976 in the south-west, and finally, in 1977 in the capital region of Helsinki.

[FIGURE2MAP]

Figure 3 illustrates the effect of the reform by displaying the number of students relative to the relevant age cohort by school type and grade level in 1970, before the nation-wide implementation of the reform, and in 1980 when most municipalities had already completed the reform. The figure shows clearly how in 1970, the cohort was divided almost evenly into primary school and general secondary school tracks after the fourth grade. In 1980, practically the whole age cohort stayed in the comprehensive school up to the ninth grade. The few remaining general secondary school students in 1980 are from the last pre-reform cohort in the capital region where the reform took place in 1977.

There are two additional observations that can be made from Figure 3. First, approximately ten percent of the students attended (experimental) comprehensive schools already before the reform. These schools were scattered across the country, but unfortunately cannot be identified in our micro-level data. Second, the general level of education was clearly rising during the 1970's. The fraction of cohort at school on the ninth grade increased from about 70 percent in 1970 to practically the entire cohort in 1980. Also the fraction of students enrolled in the upper secondary school in 1980 exceeds the number of students in the last three grades in the general secondary school in 1970 by almost twenty percent. The increase in the fraction at school at the ninth grade is mainly due to the comprehensive school reform but the increase in the upper secondary school participation rate also reflects the general increase in the demand for education. Such changes might have an independent effect on the intergenerational income elasticity so that identifying the effect of school reform on intergenerational income elasticity by simple before-after comparisons could be misleading.

[FIGURE 3, NUMBER OF STUDENTS BY GRADE LEVEL] 


\subsection{The comprehensive school reform as a quasi-experiment}

One would expect the comprehensive school reform to have an effect on the persistence of income across generations for the following reasons. First, it has often been argued that the decisions that are taken at early ages are more heavily affected by parental background. If this is the case, the postponement of tracking should decrease the effect of parental background on the track choice and decrease the intergenerational income elasticity through increased educational mobility. Second, if the academic content has a positive effect on the lifetime income of children from low income families who would otherwise not have gone to the general secondary school, the reform should also reduce intergenerational income correlation through this curriculum effect. Third, the reform kept the whole cohort in the same school for five additional years. The peer group in the comprehensive school was more heterogeneous than the peer groups in the two-track system. Holmlund (2006) shows that more diverse peer groups decreased the degree of assortative mating after a similar reform in Sweden and that the reduction of assortative mating amplifies the effects of comprehensive school on the intergenerational income correlation.

The Finnish comprehensive school reform is in many ways an ideal experiment for evaluating the effects of early versus late tracking on the intergenerational income elasticity. The regional implementation plan dictated when each municipality moved into comprehensive school system. Using a fixed-effects approach we can control for other simultaneous time trends and regional differences and purge the estimate of school system from these confounding factors.

Yet, as in any real world reform there are some caveats to the approach. First of all, as is clear from figure 2, there were exceptions to the geographical implementation plan. Some municipalities implemented the reform earlier that the rest of the municipalities in the region. The comprehensive school reform also faced intensive resistance. Most common arguments against the reform were that abolishing tracking would reduce the quality of education. As a compromise, ability tracking was partially retained within the comprehensive school. Even after the reform the students were divided into ability groups in foreign language and math classes, but studied all other subjects in their regular (not tracked) classes. This ability grouping was eventually abolished in 1985 .

The socialization of private schools under municipal ownership was also opposed especially in Helsinki where some of these schools had a distinguished reputation. After an intensive debate, it was agreed that several private schools would be allowed to survive as private alternatives to the comprehensive schools in the Helsinki region even after the reform. Many of these still exist as private senior secondary schools. Another important point to note is that in several municipalities municipality-run experimental comprehensive schools already took in almost the whole age cohort a few years before the reform. In these municipalities the founding of these schools probably had a larger effect than the subsequent transformation to a comprehensive school.

What is common to these factors is that they imply that the implementation of the reform in practice did not necessarily follow the implementation plan. One would expect these factors to attenuate the effects of the reform on intergenerational income mobility, but the size of the bias is difficult to assess. As a rough check on how contaminated the implementation of the reform actually was, we examined data from the Finnish Adult Education Surveys in 1990, 1995 and 2000. We linked the municipality where the respondents lived in 1975 to the survey data and classified these municipalities into regions according to the year when the comprehensive school reform took place in these municipalities. Then we calculated the fraction of respondents whose highest education was primary school by regions and birth cohorts. The main lesson from these calculations 
was that the reform clearly had an impact. Very few respondents report primary school as highest education after the reform and these can easily be explained by regional mobility. Also timing of the reform matches the timing of the reduction of the share with primary school as the highest education, though in most regions the fraction with only compulsory school decreases already one to two years before the reform. ${ }^{4}$

\section{Estimation methods}

Our goal is to estimate the changes in the intergenerational income elasticity due to the comprehensive school reform. The identification strategy relies on a difference-indifferences approach and exploits the fact that the reform was implemented gradually across municipalities during a six-year period.

We start with the standard specification relating the lifetime earnings of the son $\left(y_{s}\right)$ to the lifetime earnings of his father $\left(y_{f}\right)$.

$$
\log \left(y_{s}\right)=a+b_{j t} \log \left(y_{f}\right)+e
$$

The regression coefficient $b$ provides an estimate of the intergenerational income elasticity. In order to examine how the reform affected this elasticity, we allow this regression coefficient to vary across cohorts, regions, and the reform status:

$$
b_{j t}=b_{0}+\delta R_{j t}+\Omega D_{j}+\Psi D_{t}+u_{j t}
$$

where $j$ indexes municipality of residence, and $t$ the birth cohort. $R_{j t}$ is a dummy variable equal to 1 if the reform had taken place in the municipality by the time when the son was in the relevant age, $D_{j}$ the full set of municipality fixed effects, and $D_{t}$ is a full set of cohort dummies. Including full set of cohort and municipality fixed-effects allows the intergenerational income elasticity to change over time and to vary across municipalities. The only identifying assumption we impose is that the trends in intergenerational income elasticity are not systematically different in the different municipalities. The parameter $\delta$ identifies the effect of the reform on the intergenerational income elasticity.

Inserting expression (2) back into the regression equation (1) and adding the main effects of the municipality and time, as well as, the main effect of the reform produces

$$
\begin{gathered}
\log \left(y_{s, j t}\right)=a+b_{0} y_{f}+\delta\left(\log y_{f} * R_{j t}\right)+\Omega\left(\log y_{f} * D_{j}\right)+\Psi\left(\log y_{f} * D_{t}\right)+\log y_{f} * u_{j t} \\
+\Phi D_{t}+\Pi D_{j}+\Gamma R_{j t}+e_{i j t}
\end{gathered}
$$

Estimating the effect of the comprehensive school reform on intergenerational income elasticity, therefore, reduces to a model where the son's log lifetime earnings are regressed on the father's log lifetime earnings interacted with the reform dummy, and a full set of interactions between municipality and the cohort dummies and the father's lifetime earnings. ${ }^{5}$ These interactions account for general trends and regional differences in the intergenerational earnings elasticity. The effect of the reform is identified from second level interactions i.e. from the changes is father-son correlation occurring at the time of the reform after accounting for any differences across regions or trends over time.

Estimating the equation (3) involves a large number of parameters. In addition to over 400 municipality dummies one needs to add the interactions of these municipality dummies and father's earnings. This is likely to lead to intractable results. To reduce the number of parameters we aggregated the municipalities to six reform regions defined by

\footnotetext{
${ }^{4}$ Details on these calculations can be found from an appendix available upon request.

${ }^{5}$ It should be noted that equation (??) is actually a random coefficient model with a heteroskedastic error term, which needs to be accounted when calculating standard errors for the estimates.
} 
the year of reform in the municipality. Adding these region dummies already fully controls for the fact that the reform first occurred in a non-random group of municipalities.

\section{Data}

The data that we use in this paper come from the Finnish Longitudinal Census Data Files (FLCD) by Statistics Finland. Information is based on population census conducted every fifth year between 1970 and 2000. Currently the Finnish census is entirely registerbased and uses personal identity codes to merge information from various administrative registers. Up to 1980 census contained also a questionnaire mailed to every household, but even in 1970s variables such as annual earnings were based on tax registers.

Data contain information on all the 6.3 million individuals who had legal residence in Finland in at least one census year. As these data are based on administrative registers, the only reasons for the individual not to appear in the data are death and emigration. Hence, these data do not have the attrition problems that are common in the study of intergenerational earnings correlations. Census files also allow matching individuals across census years and matching family members to each other.

Our data is a 10 percent random sample from the cohorts born between 1960 and 1966 . We chose to restrict the analysis to these cohorts to have two cohorts, 1960 and 1966, with individuals only in pre- and post-reform school systems and five cohorts, 1961-1965, with individuals in both systems. We can track these individuals in all census years from 1970 to 2000. To be comparable with most of the earlier literature we focus on fathers and their sons. With our data similar analysis could also be performed for mothers and their daughters.

We measured sons' earnings as log taxable earnings in 2000. The measure includes both employment and self-employment earnings, as well as, all taxable benefits (e.g. unemployment benefits). In 2000, the youngest cohort in our sample was 34 and the oldest 40 years old. In some robustness checks we also use earnings from 1995 and take the average from these two years. The main problem in using earlier years is that Finnish students graduate relatively late. In 1995 the youngest cohorts are only 29 years of age and many have just finished school or are still studying at a university. We also experimented with trimming the data in various ways to reduce the effects of extreme observations on sons' earnings but this had only a minor effect on our estimates.

To calculate fathers lifetime earnings we took the average log taxable earnings from 1970, 1975, 1980, 1985, and 1990 all deflated to the 2000 prices. We calculated the average log earnings including all years with positive earnings. Using five years of data over a time span of twenty years reduces the bias caused by measurement error in fathers' earnings. To further reduce the effect of measurement errors, we top-coded the highest 1 percent of fathers's earnings by replacing them with 99th percentile of the fathers' earnings distribution and similarly bottom-coded the lowest one percent of fathers' earnings replacing them with the 1st percentile. We have no information on fathers' age so we cannot make further adjustments that would account for observing fathers at different ages.

Data does contain information on the municipality of residence but this information is re-coded so that individuals could not be identified. From our request the Statistics Finland classified the municipalities of residence in 1970, 1975, and 1980 to six groups according to the year when the comprehensive school reform was implemented in each municipality. We used this information together with information on the birth dates to determine whether individual was affected by the comprehensive school reform. We classified all individuals who were on the fifth grade or below when the municipality adopted the reform to the treatment (comprehensive school) group. 
The original 10\% sample of the males born during 1960-1966 contained information on 27109 individuals. Altogether 1909 of these individuals either died or moved out of the country before year 2000. For 2494 individuals the treatment status could not be identified because they moved between regions during their school years and 1622 had no father present. Finally, in most of our specifications we also drop the 260 individuals who had no positive earnings in 2000. Our final analysis sample thus contains information on 20824 individuals. Out of these, 9695 (47\%) fall into the treatment group.

In Table 1, we report some summary statistics on the age and annual earnings of our sample of individuals and their fathers. Sons' mean earnings are considerably higher than fathers' mean earnings reflecting the increase in real wages across the generations. Also the standard deviation for sons' earnings is higher, mainly because fathers' earnings are averaged across five years but sons' earnings measured based on a single year.

\section{[TABLE 1 DESCRIPTIVE STATISTICS]}

Table 2 further describes how the sample is divided into different cohorts and across the reform regions. There are no large differences in the cohort size in these age groups. The most intense reform years were $1974,-75$ and -76 . The table also shows how the treatment status depends on birth year and timing of the reform in the municipality of residence. The 1960 cohort was not affected by the reform in any region. Members of the next cohort (born 1961) were affected if they lived in a municipality that adopted the reform in 1972 when they entered the fifth grade. The shaded area in the table indicates the affected groups in the younger cohorts. The table already indicates that there are a number of potential difference-in-differences estimates that can be calculated to evaluate the effect of the reform.

\section{[TABLE 2 TIMING OF REFORM BY COHORT]}

\section{Results}

In table 3 we first report our estimates of the intergenerational elasticity of earnings separately by reform regions and birth cohorts. The first column of the upper panel displays estimates by birth cohort. There is some indication of downward trend. The elasticity falls from 0.30 for the 1960 birth cohort to 0.26 for the 1966 cohort. In addition to the effect of school reform, this drop may reflect other differences between cohorts, or the fact that intergenerational earnings elasticity tends to increase with the age when sons' earnings are measured. (Solon 2002). In the second and third columns we calculate these within cohort elasticities separately in the regions where the reform had not taken place by the time when the cohort turned eleven and in regions where the system was already reformed. The rightmost column reports the within-cohort difference between these regions. In all the birth cohorts, apart from cohort born in 1961, the estimated intergenerational earnings elasticity is lower in the regions where reform had already taken place. These differences, however, are hardly ever significant.

The bottom panel of table 3 repeats these calculations now examining changes over time within regions. Looking down in the first column one can note that there are substantial differences across regions. In the second and third column the elasticities are calculated separately for the pre- and post-reform cohorts. In all regions except the 1977 reform region, elasticity is lower among post-reform cohorts.

Table 4 presents the regression results. In column 1, we report the results of regressing the son's log earnings in 2000 on the father's average log earnings during 1970-1990 
without any control variables. The resulting coefficient is 0.277 which is somewhat higher than the earlier Finnish estimates. This is probably due to the fact that we measure sons' earnings at a later age and use five-year averages of fathers' earnings. Jäntti and Österbacka (1996) obtain an estimate of 0.22 using data for cohorts born between 1950 and 1960 with earnings measured in 1990. Österbacka (2001) obtains a much lower elasticity estimate of 0.13 using data for the same cohorts. Both of these papers use only two-year averages of fathers' earnings. Österbacka (2001) also includes sons' earnings from 1985 when the youngest sons are only 25 years old and many are still in school. Also Lucas and Pekkala (2005) report a lower estimate of 0.19 for cohorts born between 1960 and 1964 with earnings measured at age 30 .

In column 2, we add the reform dummy and the interaction between the reform dummy and father's earnings. The interaction term is -0.06 indicating that the intergenerational earnings elasticity is lower in the reform group. However, it would be wrong to interpret this difference as the effect of the reform. As is clear from table 3, there are systematic differences in the intergenerational income elasticity across both regions and cohorts and the result in column 2 may simply reflect the general downward trend in intergenerational earnings elasticity and differences in the effect of fathers earnings between the regions that adopted the reform early and those where the reform occurred later. In column 3 we account for both of these factors by adding a full set of cohort and region dummies and the interactions of these dummies with father's earnings. We normalize fathers' earnings, as well as, cohort and region dummies by subtracting the sample mean. This has no effect on our estimate of the reform effect (which is an interaction of cohort, region and fathers' earnings) but makes the other coefficients easier to interpret. For example, the main effect of fathers' earnings now refers to the average effect in the sample before the reform and not to the effect in some specific region or in a specific cohort.

The main effect of father's earnings is now 0.298 which is close to our baseline estimate in Column 1 and almost identical to the estimated pre-reform elasticity reported in Column 2. The interactions between father's earnings and cohort dummies do not indicate any clear trend in the intergenerational earnings elasticity. Regional differences are larger that the differences across cohorts. The lowest estimated intergenerational earnings correlation, 0.23, is from the region that implemented reform in 1976.

While the other coefficients have some interest, the main result in column 3 is the effect of the reform on the intergenerational earnings elasticity i.e. the coefficient of the interaction between father's earnings and the comprehensive school reform. The estimate is negative, -0.07 , and statistically significant indicating that the comprehensive school reform reduced intergenerational earnings elasticity by almost seven percentage points. This implies approximately $20 \%$ decrease in the elasticity from the pre-reform average of 0.30 .

We implemented a number of robustness checks to these results. These are reported in table 5. First, in column 1 we removed from the data all municipalities that implemented the reform before the other municipalities in the same province. In column 7 we removed observations from Helsinki region where the reform faced most intense resistance. These attempts to control for potential endogeneity in the timing of the reform had no major effects on the results. The estimates are slightly higher than the baseline estimates in Table 4, but not significantly different.

In column 3 we replaced sons earnings in 2000 with average log earnings from 1995 and 2000. This yields somewhat lower estimate (-0.047). Also the main effect of fathers' earnings decreases and is now close to earlier Finnish estimates. These results suggest that measuring sons' earnings at a younger age decreases the effects of family background perhaps because those with better educated parents tend to stay in school longer and their earnings at younger age do not yet measure lifetime earnings very precisely. Finally, 
in columns 4, 5, and 6 we remove top-coding, bottom-coding and both of these from fathers' earnings. This has virtually no effect on the results.

In table 6 , we estimate the effects of the reform using all available pairwise comparisons between cohorts and regions. For example, the first entry in the top panel uses data only from cohorts born in 1960 and 1961 and reports the difference-in-differences estimate based on the fact that only those born in 1961 who lived in the nothernmost part of the country were exposed to the reform. The next estimate compares cohorts born in 1960 to those born in 1962 and so on. Altogether there are twenty possible pairwise comparisons, thirteen of which produce a negative point estimate. Also the distribution of the estimates does not indicate that the overall estimates would be driven by some particular cohorts but rather points to there being a general tendency of decreasing effect of family background after the reform. The lower panel repeats the same exercise using fifteen possible pairwise comparisons between regions. Thirteen of these point estimates turn out to be negative. Again there is no indication of the effect being due to particular regions.

In table 7 .we examine the effects of the reform by estimating the reform effect separately in quintiles defined according to the fathers' earnings. Each column presents the results from a separate regression where sons' earnings are explained by the comprehensive school reform, and dummy variables for the cohort and the region (Coefficients of the dummy variables are not reported in the table). No cross-equation restriction on the size of the cohort or region effects are imposed, so the estimates for the reform effects are essentially nonlinear version of those reported in table 4 . The pattern of the results is striking. The effect of the reform decreases monotonously from a positive effect of 0.036 in the lowest quintile to a negative effect of -0.080 for the highest quintile. Though neither estimate is not significantly different from zero they are significantly different from each other. The negative point estimates in the highest quintiles also suggest that the comprehensive school reform may have had negative effects on some sub-groups. This could be due to a decrease in quality of education in the comprehensive school compared to the general secondary school before the reform, perhaps due to a more heterogenous and ,on average, poorer family background. However we would hesitate to make strong conclusions given large standard errors on these estimates.

\section{Conclusions}

Even though the knowledge about intergenerational earnings correlations and their differences across countries has quickly accumulated over the last ten years, understanding about the mechanisms underlying these correlations is still incomplete. Many authors have emphasized the potential role of educational institutions in shaping the intergenerational earnings mobility. Especially the role of heterogeneity in the quality early education has received attention. Yet, there is little direct evidence on the effect of educational institutions on intergenerational earnings mobility.

In this paper we estimate the effect of a major educational reform on the intergenerational earnings elasticity. The Finnish comprehensive school reform completely transformed the structure and the content of the secondary education in Finland. As a result of this reform, tracking to academic and vocational secondary education was postponed from the age 11 to 16 and a uniform academic curriculum was imposed on entire cohorts up to the ninth grade. The reform was adopted gradually by municipalities which allows us to treat this reform as a quasi-experiment.

We find that the comprehensive school reform reduced the effect of fathers' earnings on the and sons' earnings by seven percentage points. This amounts to a 20 percent drop in the intergenerational earnings correlation. These results suggest that policies that expand 
the access to academic secondary education may significantly enhance intergenerational earnings mobility.

\section{References}

[1]Aakvik, A., Salvanes, K. G., and K. Vaage, (2003): "Measuring heterogeneity in the returns to schooling in Norway using educational reforms", Centre for Economic Policy Research, Discussion paper No. 4088.

[2]Aaronson, D. and B. Mazumder, (2005): "Intergenerational economic mobility in the U.S. 1940 to 2000", Federal Reserve Bank of Chicago, WP 2005-12.

[3]Becker, G. S. and N. Tomes, (1979): "An equilibrium theory of the distribution of income and intergenerational mobility", Journal of Political Economy, 87:6, 11531189 .

[4]Becker, G. S. and N. Tomes, (1986): "Human capital and the rise and fall of families", Journal of Labor Economics, July, Part 2, 4:3, S1-S39.

[5]Björklund, A., M. Lindahl, and E. Plug, (2005): "The origins of intergenerational associationa: Lessons from Swedish adoption data", Quarterly Journal of Economics, forthcoming.

[6]Björklund, A. and M. Jäntti, (1997): "Intergenerational income mobility in Sweden compared to the United States", American Economic Review, 87:5, 110-018.

[7]Blanden, J., A. Goodman, P. Gregg, and S. Machin, (2004): "Changes in intergenerational mobility in Britain", in M. Corak (ed): Generational Income Mobility in North America and Europe, Cambridge University Press.

[8]Carneiro, P. and J. J. Heckman, (2003): "Human capital policy", in J. J. Heckman and A. B. Krueger (eds): Inequality in America: What Role for Human Capital Policies, MIT Press.

[9]Corak, K. A. and A. Heisz, (1999): "The intergenerational earnings and income mobility of Canadian men: Evidence from longitudinal income tax data", Journal of Human Resources, 34:3, 504-33.

[10]Cunha, F., J. J. Heckman, L. Lochner, and D. V. Masterov, (2005): "Interpreting the evidence on life cycle skill formation", IZA Discussion Paper No. 1675.

[11]Dearden, L., S. Machin, and H. Reed, (1997): "Intergenerational mobility in Britain", Economic Journal, 107:440, 47-66.

[12]Dustmann, C., (2004): "Parental background, secondary school track choice, and wages", Oxford Economic Papers, 56, 209-230.

[13]Jäntti, M. and E. Österbacka, (1996): "How much of the variance in income can be attributed to family background? Evidence from Finland", unpublished.

[14]Leschinsky, A. and K. U. Mayer (eds), (1990): The Comprehensive School Experiment Revisited: Evidence from Western Europe, Frankfurt am Main, Verlag Peter Lang.

[15]Meghir, C. and M. Palme, (2005): "Educational reform, ability, and parental background", American Economic Review, 95 (1), 414-424. 
[16] Österbacka, E., (2001): "Family background and economic status in Finland", Scandinavian Journal of Economics, 103, 467-484.

[17]Pekkala, S. and R. E. B. Lucas, (2006): "On the importance of finnishing school: Half a century of inter-generational economic mobility in Finland", Industrial Relations, forthcoming.

[18]Restuccia, D. and C. Urrutia, (2004): "Intergenerational persistence of earnings: The role of early and college education", American Economic Review, 94 (4), 1354-1378.

[19]Solon, G.,(1992): "Intergenerational income mobility in the United States", American Economic Review, 82:3, 393-408.

[20]Solon, G., (2002): Cross-country differences in intergenerational earnings mobility", Journal of Economic Perspectives, 16(3), 59-66.

[21]Solon, G., (2005): "A model of intergenerational mobility variation over time and place", in Corak, M. (ed).: Generational Income Mobility in North America and Europe, Cambridge University Press.

[22]Zimmerman, D.J., (1992): "Regression towards mediocrity in economic structure", American Economic Review, 82:3, 409-429. 
Figure 1 Finnish school systems before and after the comprehensive school reform

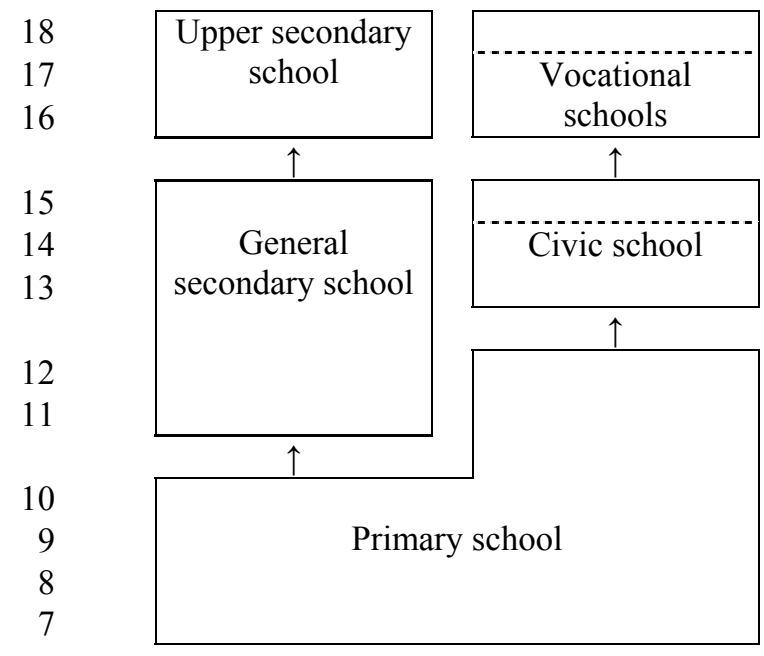

Age

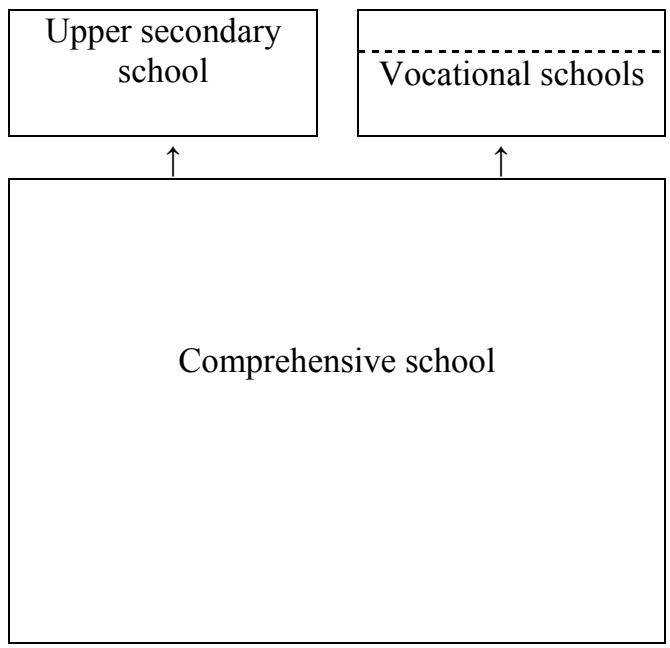

After reform 
Figure 2 The implementation of the comprehensive school reform across regions 1972-1977

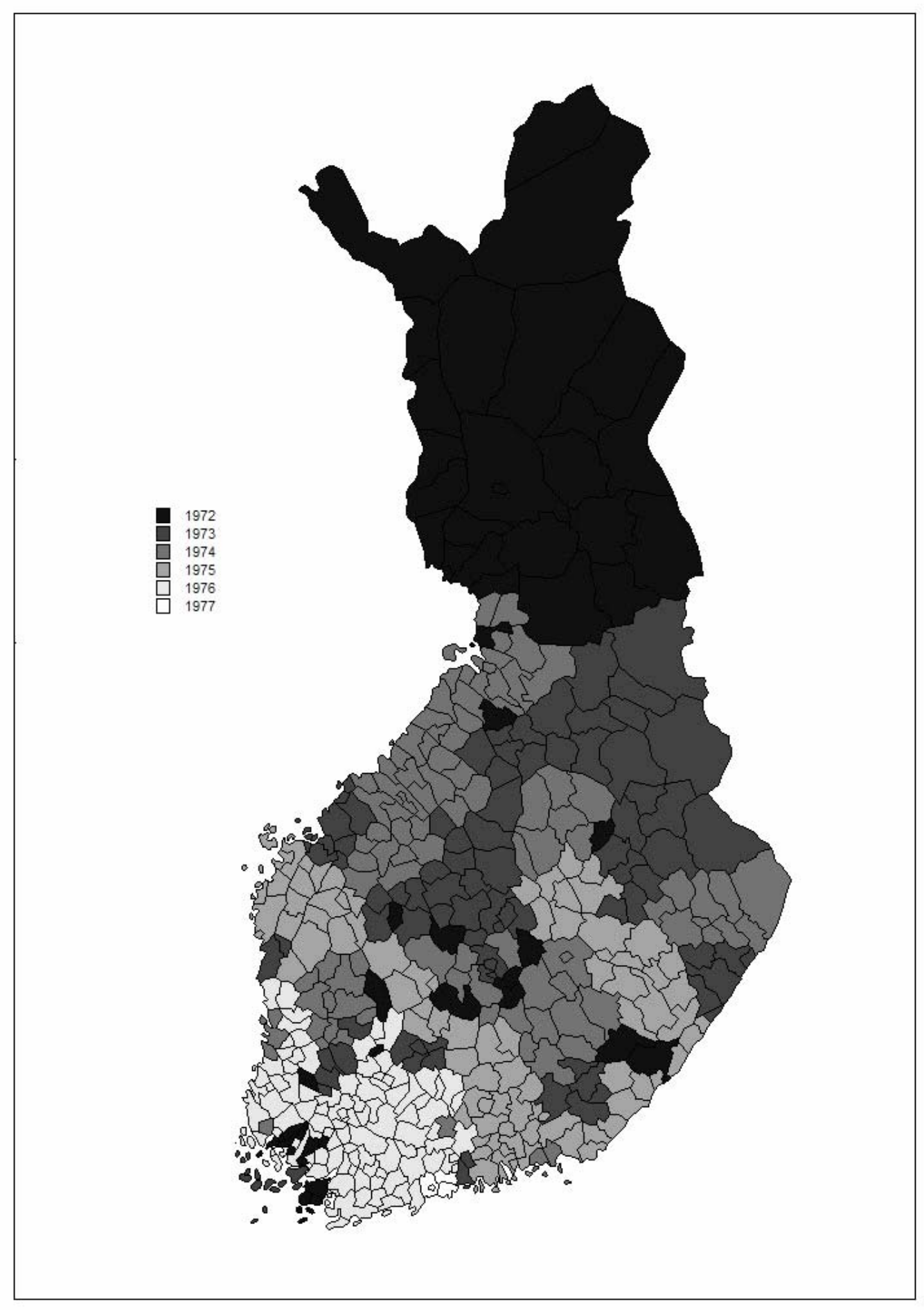


Figure 3 Number of students by grade level (as a percentage of the relevant age cohort)

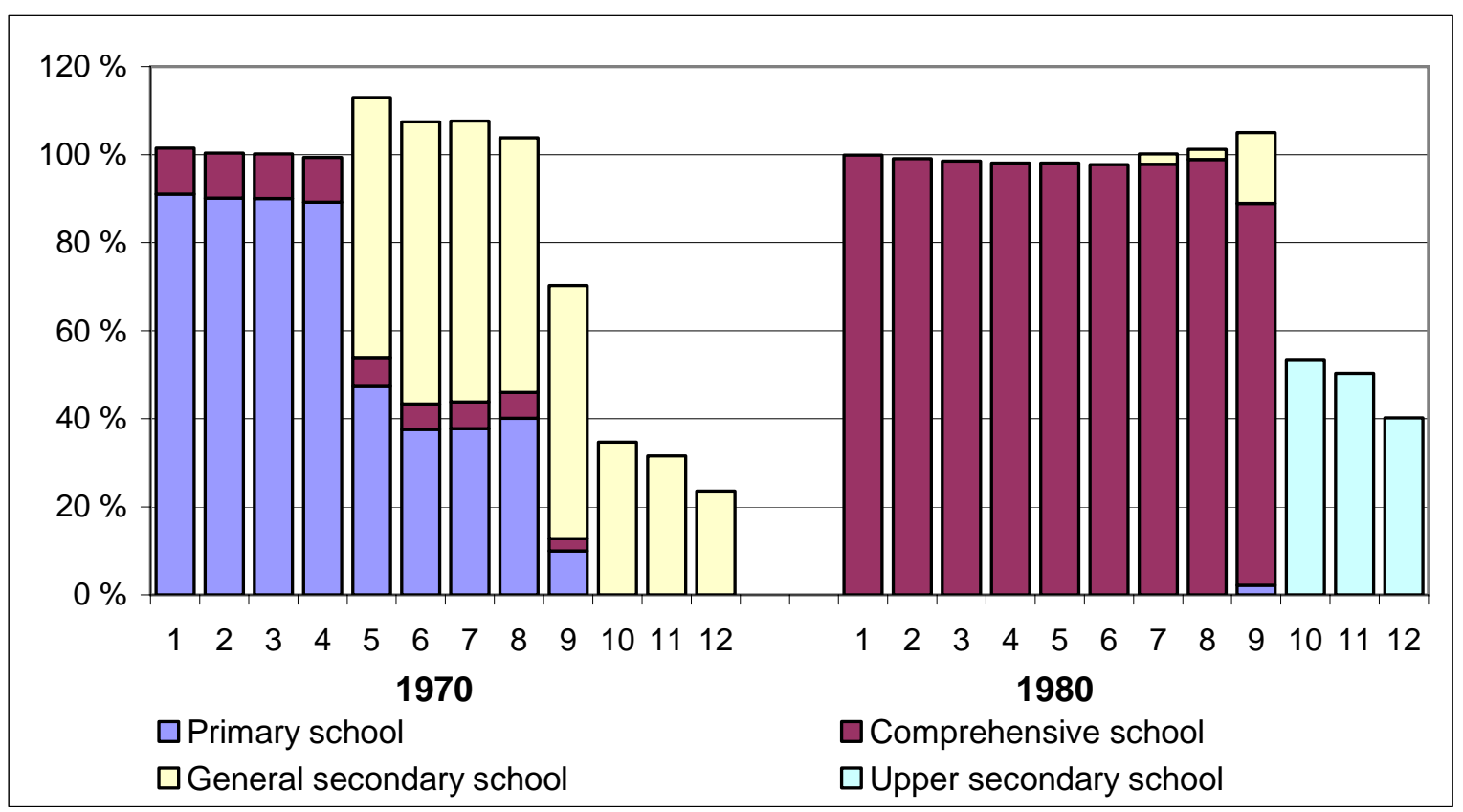

Source: Number of students by grade level and school type are reported in the Statistical Yearbook of Finland 67, 1971; Statistical Bulletin 1980:16 and Statistical Bulletin 1981:2 all by Central Statistical Office, Helsinki, Finland. Population by age group are reported in Population Census 1970, and in Population Census 1980, Part 1 Population structure and population changes, Central Statistical Office, Helsinki, Finland.

Note: The number of students at some grade levels is larger than the relevant birth cohort. This is mainly due to grade repetition in the general secondary school. According to the Statistical Yearbook, passing rates in the general secondary school were in most grade levels below 90 percent. Another reason is that some students entered general secondary school only after $5^{\text {th }}$ or $6^{\text {th }}$ grade in the primary school. Hence, though most students enter the first grade in the general secondary school in the year when they turn eleven there are also older students in the same grade level. 
Table 1 Summary statistics

\begin{tabular}{lllll}
\hline Variable & Mean & Std. Dev. & Min & Max \\
\hline Son's age in 2000 & 37.03 & 1.98 & 34 & 40 \\
Son's earnings in 2000 & 29778 & 110544 & 100 & 14916700 \\
Father's average earnings during 1970-1990 & 18687 & 11832 & 800 & 69041
\end{tabular}

Note: Summary statistics for 20786 individuals in our sample and their fathers. Earnings refer to all taxable income in 2000 prices converted to euros.

Table 2 The timing of the reform by cohorts and regions

\begin{tabular}{llllllll} 
Birth cohort & 1972 & 1973 & 1974 & 1975 & 1976 & 1977 & Total \\
\cline { 2 - 8 } 1960 & $6^{\text {th }}$ grade & 7 th grade & 8th grade & 9th grade & - & - & \\
& $\mathrm{N}=280$ & $\mathrm{~N}=437$ & $\mathrm{~N}=609$ & $\mathrm{~N}=646$ & $\mathrm{~N}=642$ & $\mathrm{~N}=348$ & $\mathrm{~N}=2,962$ \\
1961 & $5^{\text {th }}$ grade & $6^{\text {th }}$ grade & $7^{\text {th }}$ grade & $8^{\text {th }}$ grade & $9^{\text {th }}$ grade & - & \\
& $\mathrm{N}=279$ & $\mathrm{~N}=466$ & $\mathrm{~N}=624$ & $\mathrm{~N}=598$ & $\mathrm{~N}=674$ & $\mathrm{~N}=358$ & $\mathrm{~N}=2,999$ \\
1962 & $4^{\text {th }}$ grade & $5^{\text {th }}$ grade & $6^{\text {th }}$ grade & $7^{\text {th }}$ grade & $8^{\text {th }}$ grade & $9^{\text {th }}$ grade & \\
& $\mathrm{N}=311$ & $\mathrm{~N}=414$ & $\mathrm{~N}=605$ & $\mathrm{~N}=599$ & $\mathrm{~N}=649$ & $\mathrm{~N}=355$ & $\mathrm{~N}=2,933$ \\
1963 & $3^{\text {rd }}$ grade & $4^{\text {th }}$ grade & $5^{\text {th }}$ grade & $6^{\text {th }}$ grade & $7^{\text {th }}$ grade & $8^{\text {th }}$ grade & \\
& $\mathrm{N}=318$ & $\mathrm{~N}=440$ & $\mathrm{~N}=650$ & $\mathrm{~N}=648$ & $\mathrm{~N}=719$ & $\mathrm{~N}=379$ & $\mathrm{~N}=3,154$ \\
1964 & $2^{\text {nd }}$ grade & $3^{\text {rd }}$ grade & $4^{\text {th }}$ grade & $5^{\text {th }}$ grade & $6^{\text {th }}$ grade & $7^{\text {th }}$ grade & \\
& $\mathrm{N}=266$ & $\mathrm{~N}=414$ & $\mathrm{~N}=651$ & $\mathrm{~N}=630$ & $\mathrm{~N}=703$ & $\mathrm{~N}=407$ & $\mathrm{~N}=3,071$ \\
1965 & $1^{\text {st }}$ grade & $2^{\text {nd }}$ grade & $3^{\text {rd }}$ grade & $4^{\text {th }}$ grade & $5^{\text {th }}$ grade & $6^{\text {th }}$ grade & \\
& $\mathrm{N}=251$ & $\mathrm{~N}=411$ & $\mathrm{~N}=598$ & $\mathrm{~N}=623$ & $\mathrm{~N}=630$ & $\mathrm{~N}=383$ & $\mathrm{~N}=2,896$ \\
1966 & - & $1^{\text {st }}$ grade & $2^{\text {nd }}$ grade & $3^{\text {rd }}$ grade & $4^{\text {th }}$ grade & $5^{\text {th }}$ grade & \\
& $\mathrm{N}=260$ & $\mathrm{~N}=331$ & $\mathrm{~N}=586$ & $\mathrm{~N}=579$ & $\mathrm{~N}=665$ & $\mathrm{~N}=388$ & \\
\multirow{2}{*}{ Total } & $\mathrm{N}=1,965$ & $\mathrm{~N}=2,913$ & $\mathrm{~N}=4,323$ & $\mathrm{~N}=4,323$ & $\mathrm{~N}=4,682$ & $\mathrm{~N}=2,618$ & $\mathrm{~N}=20,824$ \\
\end{tabular}

Note: The shaded areas indicate cells that adopted the post-reform educational system. $\mathrm{N}$ refers to the sample size in each cell in the data that are used in the analysis. 
Table 3 Intergenerational income correlations across birth cohorts and reform regions

\begin{tabular}{lllll} 
a) Birth cohorts & \multicolumn{5}{l}{} \\
\hline Birth cohort & Average & Pre-reform & Post-reform & Difference \\
\hline 1960 & 0.303 & 0.303 & & \\
& $(0.021)$ & $(0.021)$ & & \\
1961 & 0.301 & 0.296 & 0.359 & 0.063 \\
& $(0.021)$ & $(0.022)$ & $(0.064)$ & $(0.069)$ \\
1962 & 0.294 & 0.295 & 0.271 & -0.024 \\
& $(0.021)$ & $(0.025)$ & $(0.041)$ & $(0.048)$ \\
1963 & 0.244 & 0.313 & 0.141 & -0.172 \\
& $(0.022)$ & $(0.030)$ & $(0.034)$ & $(0.045)$ \\
1964 & 0.267 & 0.240 & 0.261 & 0.021 \\
& $(0.022)$ & $(0.039)$ & $(0.028)$ & $(0.049)$ \\
1965 & 0.276 & 0.393 & 0.245 & -0.147 \\
& $(0.023)$ & $(0.070)$ & $(0.025)$ & $(0.072)$ \\
1966 & 0.262 & & 0.262 & \\
& $(0.023)$ & & $(0.023)$ &
\end{tabular}

b) Reform regions

\begin{tabular}{lllll}
\hline Region & Average & Pre-reform & Post-reform & Difference \\
\hline 1972 & 0.285 & 0.385 & 0.265 & -0.119 \\
& $(0.026)$ & $(0.068)$ & $(0.028)$ & $(0.071)$ \\
1973 & 0.234 & 0.293 & 0.211 & -0.082 \\
& $(0.021)$ & $(0.036)$ & $(0.027)$ & $(0.045)$ \\
1974 & 0.256 & 0.289 & 0.230 & -0.058 \\
& $(0.018)$ & $(0.027)$ & $(0.025)$ & $(0.037)$ \\
1975 & 0.257 & 0.273 & 0.242 & -0.031 \\
& $(0.019)$ & $(0.025)$ & $(0.031)$ & $(0.039)$ \\
1976 & 0.258 & 0.273 & 0.214 & -0.060 \\
& $(0.019)$ & $(0.021)$ & $0.038)$ & $(0.044)$ \\
1977 & 0.322 & 0.314 & 0.391 & 0.077 \\
& $(0.028)$ & $(0.030)$ & $(0.085)$ & $(0.086)$ \\
\hline
\end{tabular}

Note: Numbers in the cells are coefficients of the father's earnings in the regressions where son's earnings are regressed on father's earnings alone. Standard errors are reported in parentheses. 
Table 4 Regression results

\begin{tabular}{|c|c|c|c|}
\hline & (1) & (2) & (3) \\
\hline Father's earnings & $\begin{array}{l}0.277 \\
(0.014)\end{array}$ & $\begin{array}{l}0.297 \\
(0.011)\end{array}$ & $\begin{array}{l}0.298 \\
(0.010)\end{array}$ \\
\hline Father's earnings $\mathrm{x}$ Reform & & $\begin{array}{l}-0.055 \\
(0.009)\end{array}$ & $\begin{array}{l}-0.069 \\
(0.022)\end{array}$ \\
\hline Reform & & $\begin{array}{l}-0.063 \\
(0.012)\end{array}$ & $\begin{array}{l}-0.019 \\
(0.021)\end{array}$ \\
\hline Father's earnings x Cohort 1961 & & & $\begin{array}{l}0.005 \\
(0.030)\end{array}$ \\
\hline Father's earnings x Cohort 1962 & & & $\begin{array}{l}0.005 \\
(0.020)\end{array}$ \\
\hline Father's earnings x Cohort 1963 & & & $\begin{array}{l}-0.032 \\
(0.029)\end{array}$ \\
\hline Father's earnings x Cohort 1964 & & & $\begin{array}{l}0.003 \\
(0.036)\end{array}$ \\
\hline Father's earnings x Cohort 1965 & & & $\begin{array}{l}0.028 \\
(0.041)\end{array}$ \\
\hline Father's earnings x Cohort 1966 & & & $\begin{array}{l}0.027 \\
(0.026)\end{array}$ \\
\hline Father's earnings x Region 1973 & & & $\begin{array}{l}-0.064 \\
(0.005)\end{array}$ \\
\hline Father's earnings x Region 1974 & & & $\begin{array}{l}-0.050 \\
(0.008)\end{array}$ \\
\hline Father's earnings x Region 1975 & & & $\begin{array}{l}-0.059 \\
(0.011)\end{array}$ \\
\hline Father's earnings x Region 1976 & & & $\begin{array}{l}-0.070 \\
(0.014)\end{array}$ \\
\hline Father's earnings x Region 1977 & & & $\begin{array}{l}-0.016 \\
(0.017)\end{array}$ \\
\hline Region 1973 & & & $\begin{array}{l}0.003 \\
(0.003)\end{array}$ \\
\hline Region 1974 & & & $\begin{array}{l}0.011 \\
(0.006)\end{array}$ \\
\hline Region 1975 & & & $\begin{array}{l}0.000 \\
(0.009)\end{array}$ \\
\hline Region 1976 & & & $\begin{array}{l}0.053 \\
(0.013)\end{array}$ \\
\hline Region 1977 & & & $\begin{array}{l}0.044 \\
(0.016)\end{array}$ \\
\hline Cohort 1961 & & & $\begin{array}{l}0.025 \\
(0.023)\end{array}$ \\
\hline Cohort 1962 & & & $\begin{array}{l}-0.009 \\
(0.032)\end{array}$ \\
\hline Cohort 1963 & & & $\begin{array}{l}-0.030 \\
(0.028)\end{array}$ \\
\hline Cohort 1964 & & & $\begin{array}{l}-0.032 \\
(0.036)\end{array}$ \\
\hline Cohort 1965 & & & $\begin{array}{l}-0.049 \\
(0.033)\end{array}$ \\
\hline Cohort 1966 & & & $\begin{array}{l}-0.035 \\
(0.033)\end{array}$ \\
\hline Constant & $\begin{array}{l}10.015 \\
(0.012)\end{array}$ & $\begin{array}{l}10.043 \\
(0.010)\end{array}$ & $\begin{array}{l}10.021 \\
(0.010)\end{array}$ \\
\hline Observations & 20824 & 20824 & 20824 \\
\hline R-squared & 0.05 & 0.05 & 0.05 \\
\hline
\end{tabular}

Note: The dependent variable is son's log earnings in 2000 and father's earnings are measured with average log earnings during 1970-1990. Reform refers to the comprehensive school reform dummy. Cohorts are cohort dummies and regions are region dummies. Standard errors, reported within parentheses, are robust to clustering at the regional level. 
Table 5 Regression results - robustness checks

(1)

\begin{tabular}{lllllll} 
& $\begin{array}{l}\text { Without early } \\
\text { reformers }\end{array}$ & $\begin{array}{l}\text { Without } \\
\text { Helsinki }\end{array}$ & $\begin{array}{l}1995-2000 \\
\text { earnings }\end{array}$ & $\begin{array}{l}\text { No top- } \\
\text { coding }\end{array}$ & $\begin{array}{l}\text { No bottom- } \\
\text { coding }\end{array}$ & $\begin{array}{l}\text { No top- or } \\
\text { bottom coding }\end{array}$ \\
\hline Father's earnings & 0.311 & 0.302 & 0.251 & 0.327 & 0.340 & 0.325 \\
& $(0.022)$ & $(0.012)$ & $(0.009)$ & $(0.020)$ & $(0.024)$ & $(0.020)$ \\
Father's earnings x & -0.092 & -0.074 & -0.047 & -0.070 & -0.070 & -0.070 \\
Reform & & & & & & \\
& $(0.039)$ & $(0.022)$ & $(0.018)$ & $(0.021)$ & $(0.024)$ & $(0.022)$ \\
Reform & -0.004 & -0.008 & -0.024 & -0.018 & -0.019 & -0.018 \\
& $(0.025)$ & $(0.026)$ & $(0.019)$ & $(0.021)$ & $(0.021)$ & $(0.021)$ \\
Constant & 10.002 & 10.009 & 9.903 & 0.002 & 0.005 & 0.002 \\
& $(0.014)$ & $(0.014)$ & $(0.009)$ & $(0.018)$ & $(0.018)$ & $0.018)$ \\
Observations & 12040 & 18206 & 20824 & 20824 & 20824 & 20824 \\
R-squared & 0.05 & 0.05 & 0.06 & 0.05 & 0.06 & 0.05
\end{tabular}

Note: The dependent variable is son's log earnings in 2000 and father's earnings are measured with average log earnings during 1970-1990. In column (1), municipalities that deviate from the regional implementation plan are dropped from the sample. These are municipalities that implement the reform earlier or later than the mode of municipalities in the province. In column (2), Helsinki region that implemented the reform in 1977 is dropped from the sample. In column (3), the dependent variable is the mean of son's 1995 and 2000 earnings. In column (4), top coding at $99^{\text {th }}$ percentile is removed. In column (5), bottom coding at $1^{\text {st }}$ percentile is removed. In column (6), all coding is removed. All regressions control for a full set of regional and cohort dummies as well as their interactions with father's earnings. Reform refers to the comprehensive school reform dummy. Standard errors, reported within parentheses, are robust to clustering at the regional level. 
Table 6 Regression results - pairwise comparisons

a) By cohorts

\begin{tabular}{lllllll} 
& 1960 & 1961 & 1962 & 1963 & 1964 & 1965 \\
\cline { 2 - 7 } 1960 & & & & & & \\
1961 & -0.031 & & & & & \\
& $(0.098)$ & & & & & \\
1962 & -0.101 & 0.007 & & & & \\
& $(0.069)$ & $(0.085)$ & & & & \\
1963 & -0.195 & -0.162 & -0.151 & & & \\
& $(0.063)$ & $(0.065)$ & $(0.076)$ & & & \\
1964 & 0.029 & 0.036 & -0.007 & 0.020 & & \\
& $(0.068)$ & $(0.062)$ & $(0.063)$ & $(0.080)$ & & \\
1965 & -0.086 & -0.111 & -0.006 & -0.162 & -0.145 & \\
& $(0.101)$ & $(0.072)$ & $(0.063)$ & $(0.066)$ & $(0.085)$ & \\
1966 & -0.041 & 0.002 & -0.067 & -0.183 & 0.079 & 0.002 \\
& $(0.032)$ & $(0.105)$ & $(0.074)$ & $(0.066)$ & $(0.071)$ & $(0.105)$ \\
\hline
\end{tabular}

Note: Numbers are the coefficients of the interaction of the reform dummy and father's earnings in differences-in-differences regressions that are conducted pairwise by cohorts. Standard errors are reported within parentheses.

b) By regions

\begin{tabular}{llllll} 
& 1972 & 1973 & 1974 & 1975 & 1976 \\
\cline { 2 - 6 } 1972 & & & & & \\
1973 & 0.070 & & & & \\
& $(0.091)$ & & & & \\
1974 & -0.016 & -0.037 & & & \\
& $(0.068)$ & $(0.081)$ & & & \\
1975 & -0.039 & -0.112 & -0.162 & & \\
& $(0.065)$ & $(0.065)$ & $(0.075)$ & & \\
1976 & -0.098 & -0.072 & -0.169 & 0.017 & \\
& $(0.064)$ & $(0.057)$ & $(0.058)$ & $(0.077)$ & \\
1977 & -0.017 & -0.067 & -0.019 & 0.102 & -0.178 \\
& $(0.087)$ & $(0.071)$ & $(0.066)$ & $(0.073)$ & $(0.097)$ \\
\hline
\end{tabular}

Note: Numbers are the coefficients of the interaction of the reform dummy and father's earnings in differences-in-differences regressions that are conducted pairwise by regions. Standard errors are reported within parentheses.

Table 7 The effect of the reform on son's earnings by father's income quintiles

(1) 1st quintile of $\quad 2^{\text {nd }}$ quintile of

Reform

Constant

Observations

R-squared

9.770

(0.025)

4165

0.00

4165
(3) 3rd quintile of father's earnings father's earnings father's earnings

$\begin{array}{ll}0.036 & 0.038 \\ (0.045) & (0.040)\end{array}$

$-0.037$

$(0.038)$

10.037

$(0.021)$

4165

0.01
(4) 4th quintile of 5 th quintile of father's earnings father's earnings

$-0.051 \quad-0.080$

$(0.041) \quad(0.048)$

$10.096 \quad 10.294$

$(0.022) \quad(0.026)$

$4165 \quad 4164$

$0.00 \quad 0.01$

Note: Coefficients of the reform dummy in regressions where son's log earnings are regressed on the reform, cohort, and regional dummies and the data are split by the quintiles of the fathers' earnings distribution. Standard errors are reported in parentheses. 